\title{
31. TRACE FOSSILS IN CORES FROM DEEP SEA DRILLING PROJECT SITES 434, 435, AND 436 (JAPAN TRENCH TRANSECT)
}

\author{
Hakuyu Okada, Institute of Geosciences, Faculty of Science, Shizuoka University, Shizuoka, Japan
}

\begin{abstract}
Trace fossils are in places abundant in cores from DSDP Leg 56 sites. They are particularly rich in the pelagic-clay sequence at Site 436. Some significant trace fossils, including Zoophycos, Teichichnus, Chondrites, rind and solid burrows, and pellet-armored rods, are described. The ichnofauna, except for pellet-armored rods in diatomaceous mudstone of the landward trench slope, is characterized by cosmopolitan bathyal to abyssal forms.
\end{abstract}

\section{INTRODUCTION}

As the Deep Sea Drilling Project proceeds, data on kinds, associations, and occurrences of trace fossils in bathyal to abyssal environments have accumulated rapidly (Tracey et al., 1971, p. 424; Fullam et al., 1973; Piper and Schrader, 1973; Warme et al., 1973; van der Lingen, 1973; Ekdale, 1978; and others). Trace fossils in modern deep sea sediments are very important not only to paleontologists, but also to sedimentologists for environmental analyses of ancient sediments.

Bioturbation is a common feature of many parts of the cores from DSDP Sites 434,435 , and 436 in places (Figure 1); distinctive burrow structures are observed in places (Table 1).

This paper records some typical trace fossils for better understanding of ichnofaunas in deep-sea environments, especially in trench areas.

\section{TRACE FOSSILS}

\section{Zoophycos}

Meniscoid, tubular structures that occur usually as groups of rather straight bands of constant width (2$4 \mathrm{~mm}$ ) are identified as Zoophycos. They occur either almost horizontally (Plate 1, Figure 1; Plate 2, Figure 2) or obliquely, at a small angle from the horizontal (Plate 1, Figure 2). Some are made up of small fecal pellets (about $1 \mathrm{~mm}$ ) arranged in a crescent of slightly variable width (Plate 2, Figure 2).

The Zoophycos burrows are especially abundant in the sequence of pelagic clay and overlying radiolarian diatomaceous claystone at Site 436 , in close association with Teichichnus, Chondrites, and rind and solid burrows.

Seilacher (1967), insisting that trace-fossil communities are mainly bathymetry-controlled, established a bathymetric zonation of fossil burrows. In it, the Zoophycos zone corresponds to lower-bathyal to abyssal depths. The Zoophycos burrows at Site 436 seem to corroborate Seilacher's paleodepth scheme.

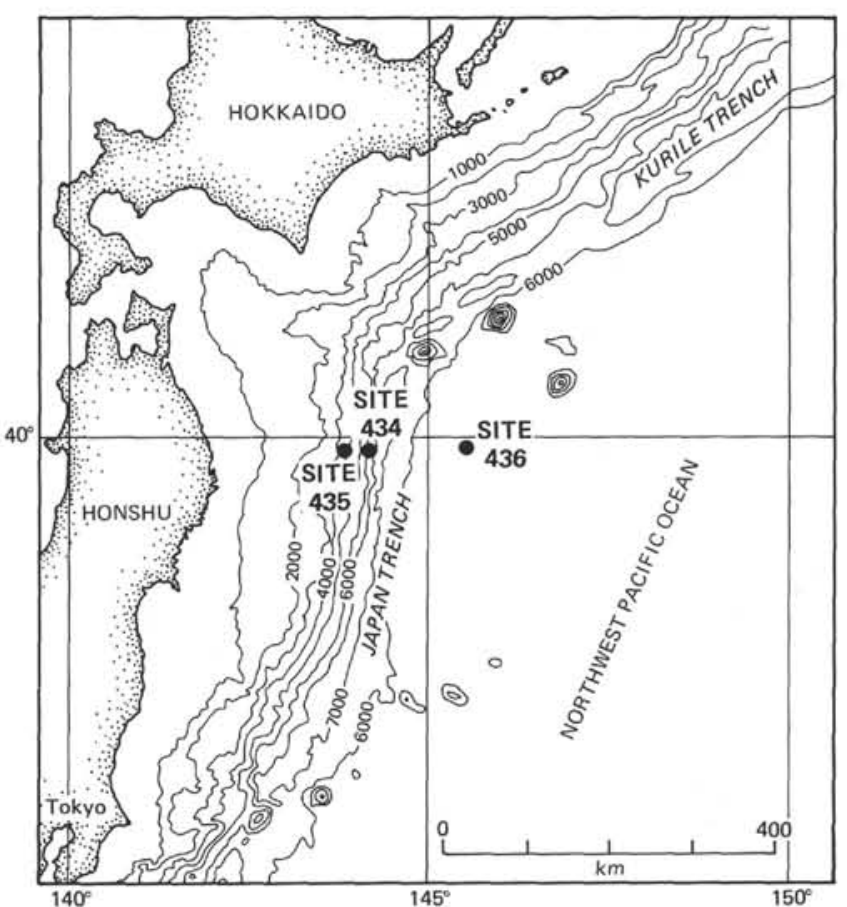

Figure 1. Locations of DSDP Leg 56 drill sites.

\section{Rind Burrow}

Chamberlain (1975) defines rind burrows as "cylindrical or subcylindrical burrows made of a light outer layer and a darker colored center".

The rind burrows in Leg 56 cores are tube-like, with a circular or ovoid cross-section, 10 to $20 \mathrm{~mm}$ in diameter (Plate 1, Figures 3, 4; Plate 2, Figure 1). They show white or tan rings of variable thickness $(1-5 \mathrm{~mm})$. The darker central part is similar to the sediment in which the rind burrow is found. In fact, an inspection of smear slides shows that there is no distinct difference in composition and texture between the central part, the ring, and the host sediment. 
TABLE 1

Typical Trace-Fossil Occurrences in Leg 56 Cores

\begin{tabular}{|c|c|c|}
\hline Core Interval & Lithology & Ape \\
\hline \multicolumn{3}{|l|}{ Zoophyces } \\
\hline $\begin{array}{l}\text { Hole } 436 \\
34-5.21-25 \mathrm{~cm}\end{array}$ & $\begin{array}{l}\text { Medium-yellowish-brown radiolarian } \\
\text { diatomaceous vitric claystone }\end{array}$ & Late Miocene \\
\hline $38-1,128-135 \mathrm{~cm}$ & $\begin{array}{l}\text { Medium-yellowish-brown radiolarian } \\
\text { vitric claystone }\end{array}$ & Middle Miocene \\
\hline $39-4.70-90 \mathrm{~cm}$ & Dusky-yellowish-brown pelagic clay & Early Miocene to Eocene \\
\hline \multicolumn{3}{|l|}{ Teichichnus } \\
\hline $\begin{array}{l}\text { Hole } 436 \\
39-40.120-130 \mathrm{~cm}\end{array}$ & Dusky-yellowish-brown pelapic day & Farly Miocene to Eocene \\
\hline \multicolumn{3}{|l|}{ Chondrites } \\
\hline $\begin{array}{l}\text { Hole } 436 \\
38-1.130-140 \mathrm{~cm}\end{array}$ & $\begin{array}{l}\text { Medium-ycllowish-brown radiolarian } \\
\text { vitric claystone }\end{array}$ & Middie Miocene \\
\hline $38-3.20-35 \mathrm{~cm}$ & $\begin{array}{l}\text { Medium-yellowish-brown radiolarian } \\
\text { vitric claystone }\end{array}$ & Middle Miocene \\
\hline \multicolumn{3}{|l|}{ Rind Burrow } \\
\hline $\begin{array}{l}\text { Holc } 435 \mathrm{~A} \\
\text { 4. (C. } 5-10 \mathrm{~cm}\end{array}$ & $\begin{array}{l}\text { Grayish-olive muddy diatomaceous } \\
\text { ooze }\end{array}$ & Early Pliocene \\
\hline $6.4 .9 \mathrm{~cm}$ & $\begin{array}{l}\text { Medium-olive-brown spicular diats- } \\
\text { maccous boze }\end{array}$ & Early Pliocene \\
\hline \multicolumn{3}{|l|}{ Hole 436} \\
\hline $38 \cdot 3.24-25 \mathrm{~cm}$ & $\begin{array}{l}\text { Medium-yellowish-brown radiolarian } \\
\text { vitric claystone }\end{array}$ & Middle Miocene \\
\hline $39-2.95 \mathrm{~cm}$ & Dusky-yellowish-brown pelagic clay & Early Miocene to Eocene \\
\hline $39-4,40-86 \mathrm{~cm}$ & Dusky-yellowish-brown pelagic clay & Early Miocene to Eocene \\
\hline \multicolumn{3}{|l|}{ Solid Burrow } \\
\hline \multicolumn{3}{|l|}{ Hole 436} \\
\hline $\begin{array}{l}39-2,35-70 \mathrm{~cm} \\
39-4,20-90 \mathrm{~cm}\end{array}$ & $\begin{array}{l}\text { Dusky-yellowish-brown pelagic day } \\
\text { Brownish-black pelagic clay }\end{array}$ & Early Miocene to Eocene \\
\hline $39-5,45-55 \mathrm{~cm}$ & Brownish-black pelagic clay & Early Miocene to Eocene \\
\hline $39-6.5-15 \mathrm{~cm}$ & Brownish-biack pelagic clay & Early Miocene to Eocene \\
\hline $40-1,85-150 \mathrm{~cm}$ & Brownish-black pelagic clay & Early Miocene to Eocene \\
\hline
\end{tabular}

At Site 436, rind burrows are common in the pelagicclay sequence from Section 39-1 to Section 40-6. They are 5 to $20 \mathrm{~mm}$ in diameter. Similar burrows are frequently reported from ocean-bottom sediments of the Cretaceous to the Pleistocene, as reviewed by Chamberlain (1975).

Forms similar to the rind burrows reported here commonly occur in the late-Miocene Tobetsu and Morai Formations and in the Pliocene Embetsu Formation exposed in northwestern Hokkaido. These formations are characterized by homogeneous, diatomaceous mudstone deposited in continental-slope environments (Plate 2, Figure 3; Klein, 1977; Okada, 1977).

\section{Solid Burrow}

The solid burrow is defined by Ekdale (1977) as "a solid, rod-like burrow with a circular cross-section 1 to $2 \mathrm{~cm}$ in diameter."

Solid burrows in Leg 56 cores show a solid, lightcolored (white or yellowish-brown), circular or ovoid cross-section (Plate 1, Figure 3; Plate 2, Figure 1). They range from a few to $30 \mathrm{~mm}$ across. The burrows occur in soft, dusky-yellowish-brown to brownish-black pelagic clay from Section 39-2 to Section 40-6 at Site 436, ranging in sub-bottom depth from 361 to 378 meters. This sequence is assigned to the Miocene.

These forms are closely associated with the rind burrows. Therefore, the genesis of the solid burrow may be much the same as that of the rind burrow. As Ekdale
(1977) suggested, the solid burrow may represent final products in a chemical-reduction process.

\section{Pellet-Armored Rod}

Two pieces of pellet-armored rods were found in grayish-olive-green, diatomaceous claystone from Section 19-2 and Section 23-3 at Site 434.

Both the pieces show straight, tubular form, with elliptical cross-section. In Section 19-2, they are less than $25 \mathrm{~mm}$ across and $29 \mathrm{~mm}$ long; in Section 23-3, they are 22 by $13 \mathrm{~mm}$ across and $38 \mathrm{~mm}$ long. These rods are covered wholly with small lumpy or pellet-like sculptures. Single sculptures, 1 to $5 \mathrm{~mm}$ long and 0.5 to $1 \mathrm{~mm}$ wide, are protruded and arranged almost parallel to the length of the rod. Larger sculptures are seen on broad sides.

The internal part of the rod is a little darker than the marginal part, but no distinct structural and compositional differences are recognized. The rods consist of diatomaceous, micritic limestone or marlstone (Plate 3, Figures 3,4 ), in places with scattered fecal pellets (Plate 3, Figure 3). This lithology is similar to that of carbonate nodules frequently found in Site 434 cores (Okada, this volume).

These lithified burrows look like Ophiomorpha of Häntzschel (1952), but are not identical, in that Ophiomorpha is characterized by transversely arranged, lumpy sculptures on the surface and a well-defined, thick wall.

These structures may be autochthonous, but their occurrence is obscured by drilling disturbance; most carbonate nodules with similar lithology nature are interpreted as autochthonous (Okada, this volume).

\section{Other Trace Fossils}

Other distinct burrows found in Leg 56 cores are Teichichnus and Chondrites. Teichichnus occurs in duskyyellowish-brown clay at Site $\mathbf{4 3 6}$ as a short, vertical burrow, $5 \mathrm{~mm}$ wide, with tightly packed, concave-down, crescentic laminae (Plate 1, Figure 2). Chondrites is observed as groups of circular or elongated, dark-colored dots (Plate 1, Figures 1, 4). It is also found in radiolarian vitric claystone at Site 436 (Table 1).

Color mottling and bioturbation are also common in many cores from Sites 434,435 , and 436 , and bioturbation is remarkable below 304 meters sub-bottom at Site 436 .

\section{CONCLUDING REMARKS}

Trace fossils in Leg 56 cores are Zoophycos, Teichichnus, Chondrites, rind burrow, solid burrow, pelletarmored rod, and others. These trace fossils, except for the pellet-armored rod, are common in diatomaceous clay and brownish-black pelagic clay cored at Site 436 . They seem to be confined to a very slowly deposited sequence. This trace fossil assemblage is in good accord with the deep-sea fossil community of Chamberlain (1975). Pellet-armored rods found in diatomaceous claystone at Site 434 are difficult to evaluate.

\section{ACKNOWLEDGMENTS}

The photographs used in this study were taken by Mr. Victor Sotelo (Deep Sea Drilling Project, Scripps Institution of Oceanog- 
raphy), to whom I am indebted. Thanks are extended to Dr. Toyosaburo Sakai (Tohoku University) for his discussions and help in reproducing the photographs.

I would like to thank Drs. Hiroshi Noda (Tsukuba University) and Kiyotaka Chinzei (University of Tokyo) for critically reading the manuscript.

This study was supported by the Japanese Scientific Advisory Board for the International Phase of Ocean Drilling, and in part by a Grant-in-Aid for Scientific Researches from the Ministry of Education, Japan (Grant N. 246037).

\section{REFERENCES}

Chamberlain, C. K., 1975. Trace fossils in DSDP cores of the Pacific. Paleontology, 49, 1074-1096.

Ekdale, A. A., 1977. Abyssal trace fossils in worldwide Deep Sea Drilling Project cores. In Crimes, T. P., and Harper, J. C. (Eds.), Trace fossils 2, Geol. J., Spec. Issue 9, 163-182.

Ekdale, A. A., 1978. Trace fossils in Leg 42A cores. In Hsü, K. J., Montadert, L., et al., Init. Repts. DSDP, 42, Part 1: Washington (U.S. Govt. Printing Office), 821-827.

Fullam, T. J., Supko, P. R., Boyce, R. E., and Stewart, R. J., 1973. Some aspects of late Cenozoic sedimentation in the Bering Sea and North Pacific Ocean. In Creager, J. S., Scholl, D. W., et al., Init. Repts. DSDP, 19: Washington (U.S. Govt. Printing Office), 887-896.
Häntzschel, W., 1952. Die Lebensspuren von Ophiomorpha Lundgren im Miozän bei Hamburg, ihre welteweite Vebreitung und Synonymie. Mitt. Geol. Staats. Hamburg, 21, 142-152.

Klein, G. deV., 1977. Sedimentary facies and depositional style. Bull. Nat. Sci. Museum., Ser. C, 3, 63-69.

Okada, H., 1977. Mineralogy, petrology and sedimentary history. Bull. Nat. Sci. Museum, Ser. C, 3, 69-77.

Piper, D. J., and Schrader, H. J., 1973. Bioturbation of sediments. In Kulm, L. D., von Huene, R., et al., Init. Repts. DSDP, 18: Washington (U.S. Govt. Printing Office), 869875.

Seilacher, A., 1967. Bathymetry of trace fossils. Mar. Geol., 5, 413-428.

Tracey, J. I., Jr., Sutton, G. H., et al., 1971. Site 71. In Tracey, J. I., Jr., et al., Init. Repts. DSDP, 8: Washington (U.S. Govt. Printing Office), 285-458.

van der Lingen, G. J., 1973. Ichnofossils in deep sea cores from the southwest Pacific. In Burns, R. E., Andrews, J. E., et al., Init. Repts. DSDP, 21: Washington (U.S. Govt. Printing Office), 693-700.

Warme, J. E., Kennedy, W. J., and Schneidermann, N., 1973. Biogenic sedimentary structures (trace fossils) in Leg 51 cores. In Edgar, N. T., Saunders, J. R., et al., Init. Repts. DSDP, 15: Washington (U.S. Govt. Printing Office), 813-831. 


\section{PLATE 1}

Figure $1 \quad$ Vertical section through two Zoophycos spreiten $(\mathrm{Z})$ and Chondrites burrows $(\mathrm{C})$ in vitric radiolarian claystone. Interval 436-38-1, 129-141 cm. Water depth at Site 436 is 5240 meters.

Figure 2 Vertical section through a Teichichnus burrow (T) and many Zoophycos-type burrows in the lower half of the photograph. The sediment is pelagic clay. Interval $436-39-4,118-132 \mathrm{~cm}$.

Figure 3 Vertical section through two solid burrows (S), and rind burrows in the lower part. The sediment is pelagic clay. Interval $436-39-5,44-56 \mathrm{~cm}$.

Figure 4 Vertical section through rind burrows (R), and Chondrites burrows in the lower part, in vitric radiolarian claystone. Interval 436-38-3, 20-35 $\mathrm{cm}$. 
Plate 1
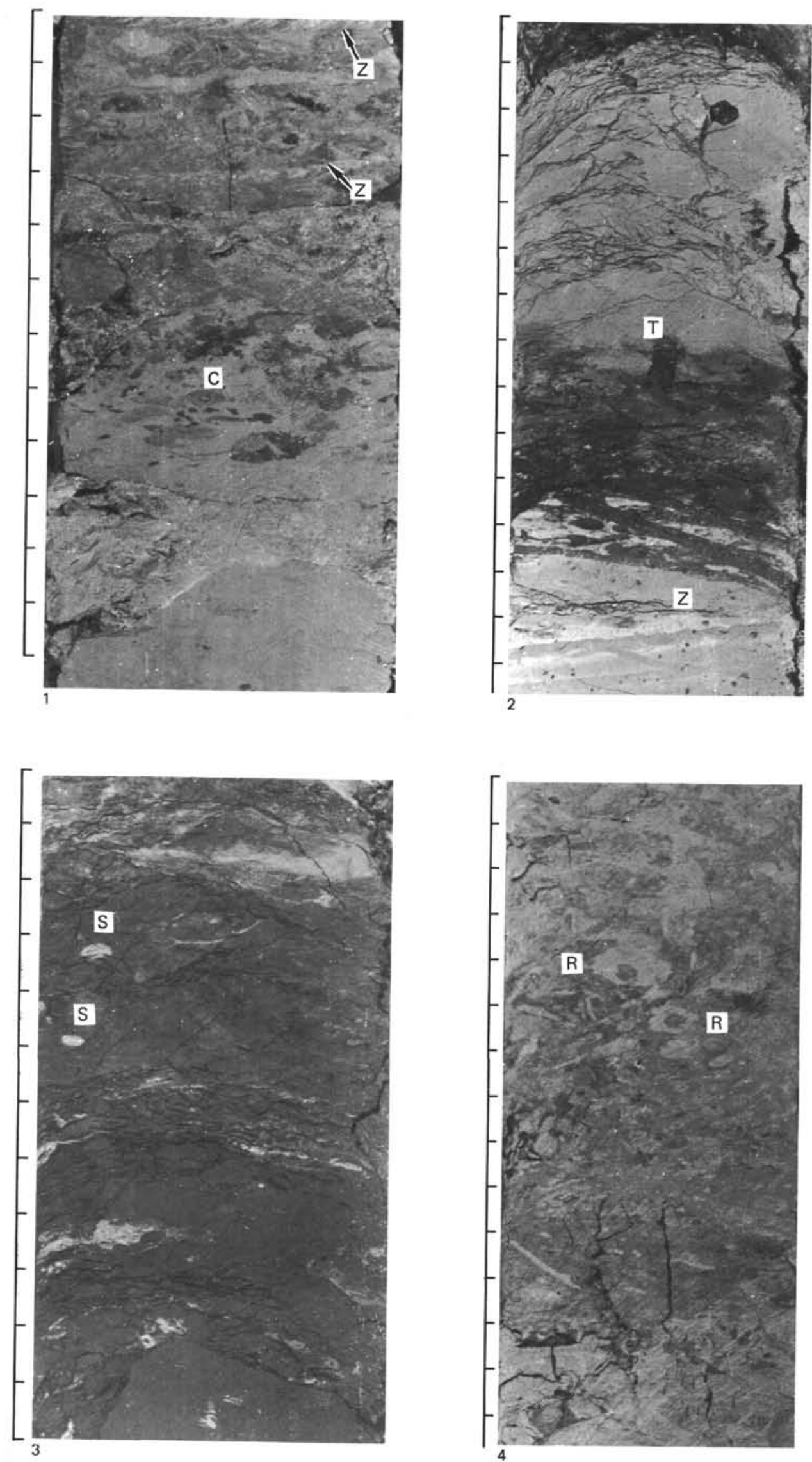


\section{PLATE 2}

Figure 1 Vertical section through solid burrows (S) and a rind burrow in pelagic clay. Interval $436-39-4$, $69-90 \mathrm{~cm}$.

Figure 2 Vertical section through two Zoophycos spreiten (Z) filled with fecal pellets, in siliceous vitric claystone. Interval 436-34-5, 8-25 cm.

Figure 3 Rind burrows from Pliocene diatomaceous mudstone in northwestern Hokkaido (Embetsu Formation exposed south of Embetsu). 
PLATE 2
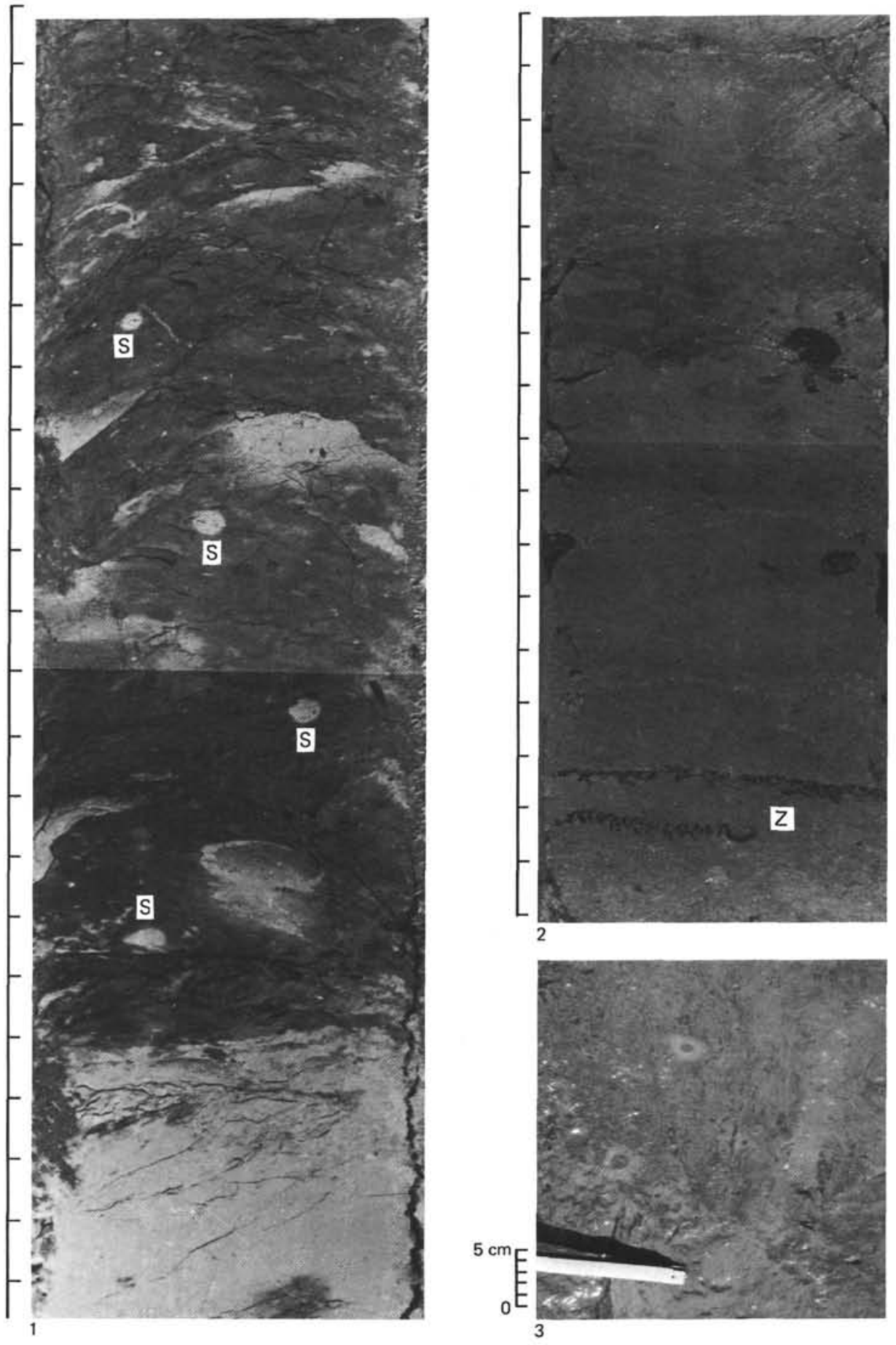


\section{PLATE 3}

Figures 1, 2 Pellet-armored rods. Figure 1 shows a rod from clayey diatomite to diatomaceous claystone from Section 434-23-3. Figure 2 shows a rod from diatomaceous claystone from Section 434-19-2. Water depth at Site 434 is 5986 meters.

Figures 3, 4 Photomicrographs of a thin-section of a rod from Section 434-23-3, showing carbonate minerals with microcrystalline texture. Note geopetal situation of pyrite in diatom host cavities (Figure 3) and scattered fecal pellets (Figure 4). Plane polarized light. 


\section{PLATE 3}

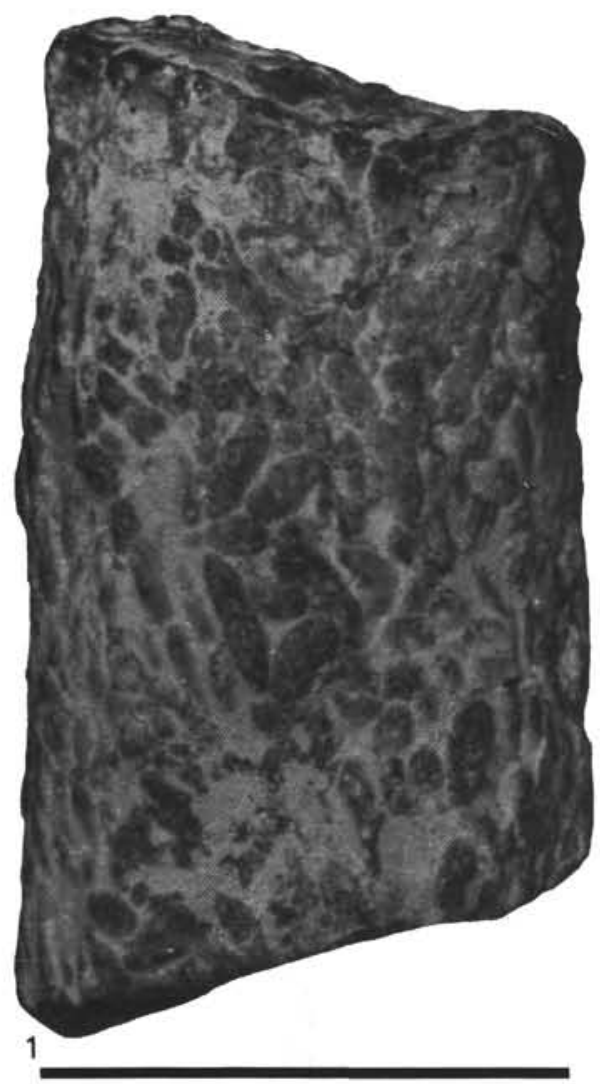

$2 \mathrm{~cm}$

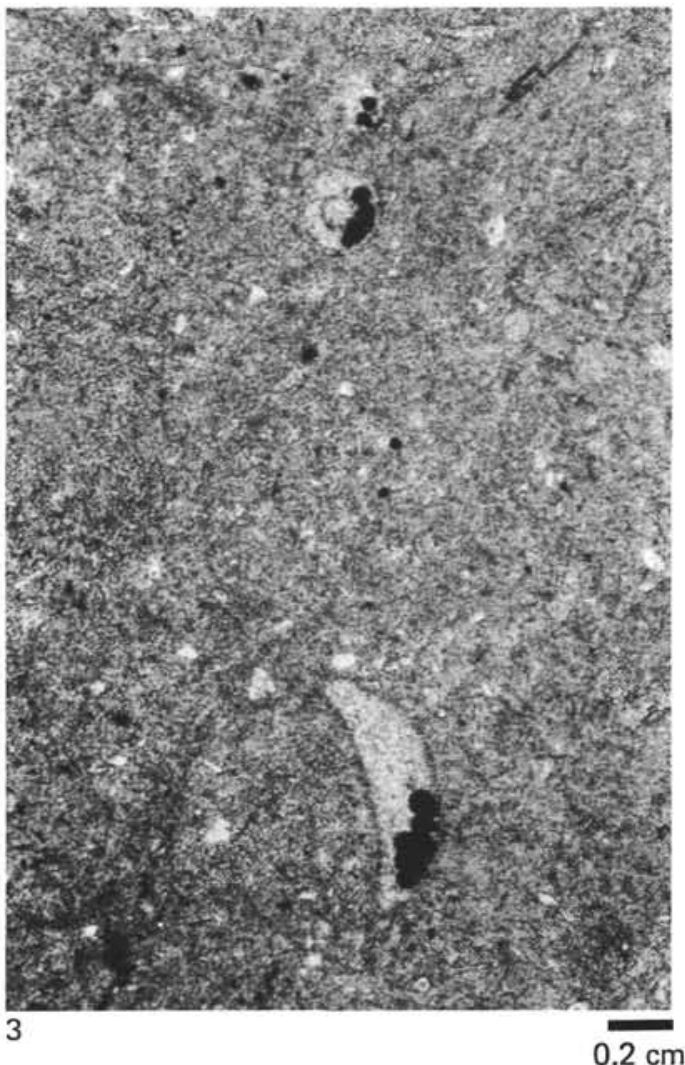

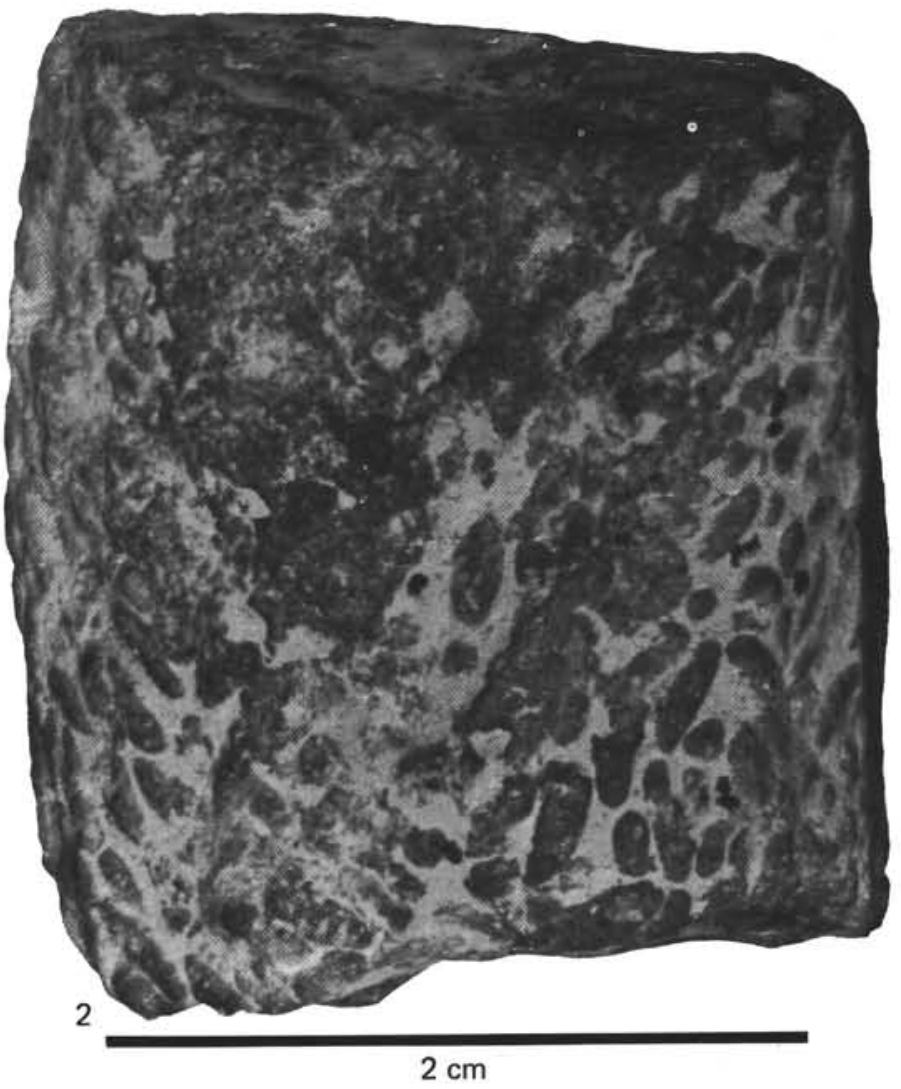

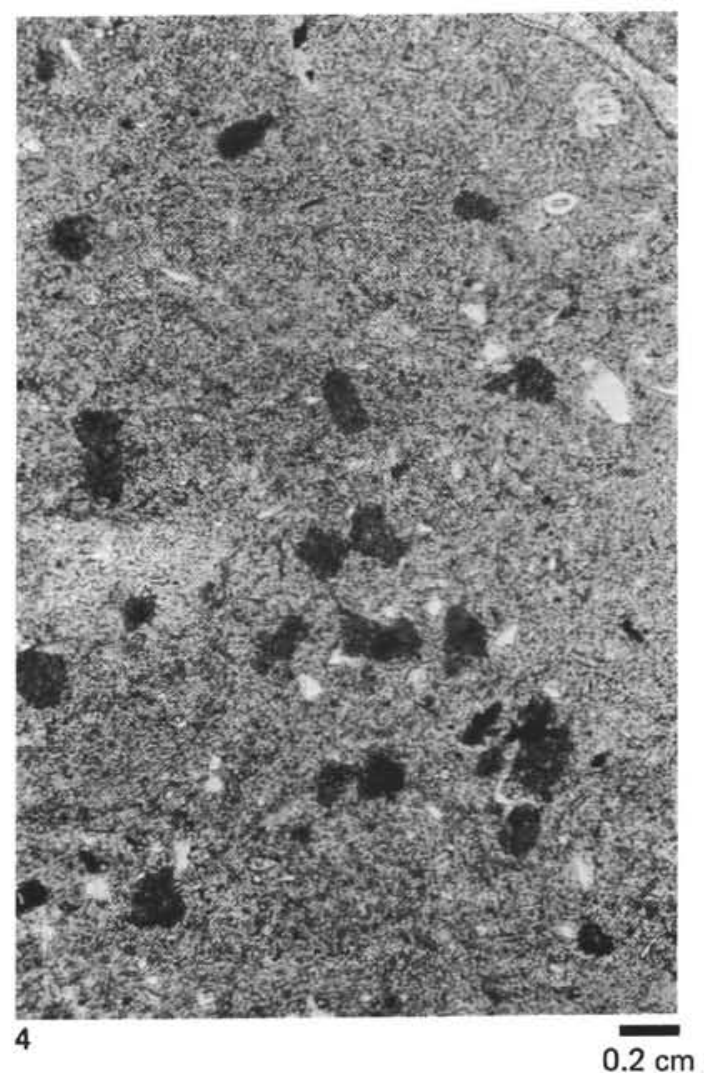

